\title{
A randomized controlled trial comparing oxytocin administration before and after placental delivery in the prevention of postpartum haemorrhage in a tertiary care hospital in Bankura district of West Bengal, India
}

\author{
Rahul Kirtania $^{1}$, Jayita Pal ${ }^{2 *}$, Sisir Biswas ${ }^{3}$, Aditi Aich ${ }^{1}$
}

\begin{abstract}
${ }^{1}$ Department of Gynecology and Obstetrics, Bankura Sammilani Medical College and Hospital, Bankura, West Bengal, India

${ }^{2}$ Department of Maternal and Child Health, Institute of Public Health, Kalyani, Nadia, West Bengal, India

${ }^{3}$ Department of Gynecology and Obstetrics, Burdwan Medical College and Hospital, Burdwan, West Bengal, India
\end{abstract}

Received: 17 February 2020

Accepted: 27 March 2020

\section{*Correspondence:}

Dr. Jayita Pal,

E-mail: docjayita.pal@ rediffmail.com

Copyright: () the author(s), publisher and licensee Medip Academy. This is an open-access article distributed under the terms of the Creative Commons Attribution Non-Commercial License, which permits unrestricted non-commercial use, distribution, and reproduction in any medium, provided the original work is properly cited.

\section{ABSTRACT}

Background: PPH is the prime cause of maternal mortality worldwide. The incidence of PPH can be drastically combatted by application of uterotonic in active management of third stage labour. Timing of its administration is a matter of concern. This study aimed to assess whether timing of administration of oxytocin would have any impact on incidence or mean blood loss of PPH.

Methods: It was a single blinded randomized controlled trial conducted in the department of Obstetrics and Gynecology, Bankura Sammilani Medical College for 6 months where 100 antenatal mothers admitted for normal delivery in labour room were allocated randomly in study and control group considering inclusion and exclusion criteria. Incidence of PPH and mean blood loss had been identified clinically by following them for 24 hours.

Results: Only $9 \%$ of study population had experienced PPH. There was no statistically significant difference in incidence of PPH with difference in timing of administration of oxytocin ( $p>0.05$ ). But there was statistically significant decrease in mean blood loss if oxytocin was administered before the placental delivery. The mean blood loss with oxytocin administered before placental delivery was $296.8 \mathrm{ml}$ (102.45) and after placental delivery was 452.0 (128.87) $\mathrm{ml}$ respectively.

Conclusions: Policy makers should keep in mind not only the incidence of PPH, but the mean blood loss amount too in a setting where anaemia in pregnancy is quite prevalent.

Keywords: Haemorrhage, Oxytocin, Postpartum, Trial

\section{INTRODUCTION}

Postpartum haemorrhage (PPH) is the major culprit for around $25 \%$ of total maternal deaths all over the world and also one of the commonest causes of maternal mortality in low-income countries. ${ }^{1}$ It is defined as blood loss greater than or equal to $500 \mathrm{ml}$ within 24 hours after birth and if blood loss is greater than or equal to $1000 \mathrm{ml}$ within 24 hours it is denoted as severe PPH. Primary PPH which occurs within first 24 hours following delivery majorly causes high morbidity and mortality, while secondary PPH is denoted as any abnormal or excessive bleeding from the birth canal occurring between 24 hours and 12 weeks. $^{2}$ 
Other than uterine atony which is the most common cause of PPH and thereby maternal mortality; genital tract trauma (i.e. vaginal or cervical lacerations), uterine rupture, retained placental tissue, or maternal bleeding disorders also lead to the same event. ${ }^{2}$

Prevalence of PPH ranges from $2 \%$ to as high as 11-18 percent of natural, unmedicated childbirths and is the leading cause of maternal morbidity in developed countries too. ${ }^{3-5}$ It also leads to severe maternal morbidity, disability including shock, organ dysfunction and sequelae like occult myocardial ischemia, dilutional coagulopathy and the severest forms of haemorrhagic shocks may lead to anterior pituitary ischemia with delay or failure of lactation (i.e., postpartum pituitary necrosis). ${ }^{3,6-8}$ Postpartum anaemia resulting from haemorrhage increases the risk of postpartum depression. ${ }^{9}$ Blood transfusion may be required which carries associated risks. ${ }^{10}$

Risk factors for PPH include grand multiparity, multiple gestations, prolonged third stage of labour, episiotomy, foetal macrosomia, pre-existing anaemia and history of postpartum hemorrhage. ${ }^{11-15}$ However, PPH may occur in women without identifiable clinical or historical risk factors.

An approach called "active management of the third stage of labour" which consisted of steps like administration of a uterotonic soon after the birth of the baby, clamping of the cord following the observation of uterine contraction (at around 3 minutes) and delivery of the placenta by controlled cord traction, followed by uterine massage has been introduced for prevention of $\mathrm{PPH}^{2,3}$ Evidences showed that in comparison to expectant management, the active management can substantially reduce events of $\mathrm{PPH}^{3}$

The timing of administration of prophylactic oxytocic drugs in active management is a controversial issue. Conventionally it is recommended to administer relevant drugs at the time of delivery of the anterior shoulder. This fixed timing can create complication in practice due to manpower constraints in relation to delivery rushes especially in low-income countries. ${ }^{16}$

Various researches are conducted to find out the effective and convenient time of administration of oxytocin during delivery which will prevent PPH and also bring out operational feasibility. ${ }^{1,16-19}$ But there is scarcity of the same in Bankura district of West Bengal. With this backdrop, the present study had been taken up to find out the ideal timing of oxytocin administration in the "active management of third stage of labour" to prevent postpartum haemorrhage.

\section{METHODS}

An institution based single blinded randomized controlled trial had been conducted in the department of Obstetrics and Gynecology, Bankura Sammilani Medical College between April 2019 to September 2019. All pregnant mothers coming for vaginal delivery in the labour room of Bankura Sammilani Medical College were the study population. Mothers who were not giving consent, seriously ill, mentally challenged, having a history of previous caesarean section/PPH or experiencing multiple gestation, antepartum hemorrhage, hypertensive disorder of pregnancy, or bleeding disorder were excluded from the study. Institutional ethical clearance had been obtained before commencement of the study.

Table 1: Distribution of study population according to socio-demographic characteristics $(n=100)$.

\begin{tabular}{|c|c|c|}
\hline Variable & Frequency (n) & $\begin{array}{l}\text { Percentage } \\
(\%)\end{array}$ \\
\hline \multicolumn{3}{|c|}{ Age (completed years) } \\
\hline$<20$ & 34 & $34.0 \%$ \\
\hline $20-30$ & 59 & $59.0 \%$ \\
\hline$\geq 30$ & 7 & $7.0 \%$ \\
\hline \multicolumn{3}{|l|}{ Religion } \\
\hline Hindu & 90 & $90.0 \%$ \\
\hline Muslim & 10 & $10.0 \%$ \\
\hline \multicolumn{3}{|c|}{ Educational qualification (in completed standard) } \\
\hline Class I & 4 & $4.0 \%$ \\
\hline Class V & 26 & $26.0 \%$ \\
\hline Secondary & 49 & $49.0 \%$ \\
\hline Graduate & 12 & $12.0 \%$ \\
\hline Post graduate & 9 & $9.0 \%$ \\
\hline \multicolumn{3}{|c|}{ Socio-economic status* } \\
\hline I & 1 & $1.0 \% \%$ \\
\hline II & 12 & $12.0 \%$ \\
\hline III & 73 & $73.0 \%$ \\
\hline IV & 11 & $11.0 \%$ \\
\hline $\mathrm{V}$ & 3 & $3.0 \%$ \\
\hline \multicolumn{3}{|l|}{ Parity } \\
\hline 0 & 73 & $73.0 \%$ \\
\hline 1 & 26 & $26.0 \%$ \\
\hline 2 & 1 & $1.0 \%$ \\
\hline \multicolumn{3}{|l|}{ Gravida } \\
\hline 1 & 70 & $70.0 \%$ \\
\hline 2 & 28 & $28.0 \%$ \\
\hline 3 & 1 & $1.0 \%$ \\
\hline 4 & 1 & $1.0 \%$ \\
\hline \multicolumn{3}{|c|}{ Number of living issue } \\
\hline 0 & 81 & $81.0 \%$ \\
\hline 1 & 18 & $18.0 \%$ \\
\hline 2 & 1 & $1.0 \%$ \\
\hline
\end{tabular}

*assessed by modified B.G. Prasad scale (2018).

Sample size for the proposed study had been calculated based on the formula using test of difference in proportions and considering both alpha and beta error. The total minimum sample size had been estimated to be 36 (18 in each group) considering confidence interval at $95 \%$, power at $80 \%$, the proportions of success (nonoccurrence of postpartum hemorrhage) with conventional and new intervention (application of oxytocin before 
placental delivery) at $98.5 \%$ and $98 \%$ respectively and assuming the minimum difference between two proportions for having a discernible clinical benefits be 25. All the mothers delivering in the labour room of Bankura Sammilani Medical College during the data collection period who had given informed consent and were fulfilling the inclusion and exclusion criteria under the study had been included by complete enumeration method and allocated randomly in study and control group. Exit interview of mothers had been conducted with the help of a predesigned interview schedule to note down socio-demographic characteristics and medical profile of the patients followed by clinical observation to find out occurrence of postpartum hemorrhage. The study group was given new intervention i.e. 10 units of oxytocin in a $500 \mathrm{ml}$ crystalloid intravenous solution just after the delivery of anterior shoulder (i.e. before placental delivery) and the control group received conventional 10 units of oxytocin in a $500 \mathrm{ml}$ crystalloid intravenous solution just after the delivery of placenta. For all patients, the third stage of labour had been managed with controlled cord traction until placental expulsion, followed by at least 15 seconds of fundal message. Both the groups were clinically observed for 24 hours following delivery to identify incidence of postpartum hemorrhage.

\section{Statistical analysis}

Data were entered in SPSS 20.0 version and analyzed with descriptive and inferential statistics. All the analyses were two tailed with $\mathrm{p}$ value $<0.05$ being significant.

\section{RESULTS}

Majority of the study population belonged to the age group of 20-30 years (59\%) with mean of 22 (3.84) years. Most of them were Hindu ( $90 \%)$, completed secondary education (49\%), belonged to socio-economic class III $(73 \%)$, nullipara $(73 \%)$, primigravida $(70 \%)$ and did not have any living issue $(81 \%)$. None of them suffered from or had previous history of diabetes, hypertension, oedema, jaundice or bleeding per vagina. All of them had a normal pulse rate with a mean of 81.37 (4.519) and blood pressure; while majority $(62 \%)$ of study population were suffering from anaemia with a mean $\mathrm{Hb} \%$ of 11.01 (0.773) gm\%. Only 9\% of study population had experienced PPH (Table 1).

Table 2: Comparability between study and control group $(n=100)$.

\begin{tabular}{|c|c|c|c|}
\hline \multirow{2}{*}{ Variables } & \multicolumn{2}{|c|}{ Timing of administration of oxytocin } & \multirow{2}{*}{ Test of significance } \\
\hline & Before placental delivery (n) & After placental delivery (n) & \\
\hline \multicolumn{3}{|l|}{ Gravida } & \multirow{3}{*}{$\begin{array}{l}\text { Chi-square }=1.714 \\
\mathrm{df}=1, \mathrm{p}=0.190\end{array}$} \\
\hline 1 & 38 & 32 & \\
\hline$>1$ & 12 & 18 & \\
\hline \multicolumn{3}{|l|}{ Age } & \multirow{3}{*}{$\begin{array}{l}\text { Chi-square }=0.364 \\
\mathrm{df}=1, p=0.546\end{array}$} \\
\hline$\leq 21($ median $)$ & 29 & 26 & \\
\hline$>21$ & 21 & 24 & \\
\hline \multicolumn{3}{|l|}{ Religion } & \multirow{3}{*}{$\begin{array}{l}\text { Chi-square }=1.778 \\
\mathrm{df}=1, \mathrm{p}=0.182\end{array}$} \\
\hline Hindu & 47 & 43 & \\
\hline Muslim & 3 & 7 & \\
\hline \multicolumn{3}{|l|}{ Education } & \multirow{3}{*}{$\begin{array}{l}\text { Chi-square }=0.542 \\
\mathrm{df}=1, \mathrm{p}=0.461\end{array}$} \\
\hline Up to secondary & 41 & 38 & \\
\hline Graduate and above & 9 & 12 & \\
\hline \multicolumn{3}{|l|}{ Socio-economic status } & \multirow{3}{*}{$\begin{array}{l}\text { Chi-square }=1.329 \\
\mathrm{df}=1, \mathrm{p}=0.249\end{array}$} \\
\hline Up to class III & 45 & 41 & \\
\hline IV and V & 5 & 9 & \\
\hline \multicolumn{3}{|l|}{ Parity } & \multirow{3}{*}{$\begin{array}{l}\text { Chi-square }=2.486 \\
\mathrm{df}=1, \mathrm{p}=0.115\end{array}$} \\
\hline 0 & 40 & 33 & \\
\hline$>1$ & 10 & 17 & \\
\hline
\end{tabular}

Table 3: Distribution of study population according to timing of administration of oxytocin and incidence of PPH (n=100).

\begin{tabular}{|c|c|c|c|}
\hline \multirow{2}{*}{ Timing of administration of oxytocin } & \multicolumn{2}{|l|}{ PPH } & \multirow{2}{*}{ Test of significance } \\
\hline & Yes n $(\%)$ & No $n(\%)$ & \\
\hline Before delivery & $2(4.0)$ & $48(96.0)$ & \multirow{2}{*}{$\begin{array}{l}\text { Chi-square }=3.053 \\
\mathrm{df}=1, \mathrm{p}=0.081\end{array}$} \\
\hline After delivery & $7(14.0)$ & $43(86.0)$ & \\
\hline
\end{tabular}


Table 4: Relationship of mean blood loss and timing of administration of oxytocin $(n=100)$.

\begin{tabular}{|llllllll|}
\hline $\begin{array}{l}\text { Timing of administration } \\
\text { of oxytocin }\end{array}$ & $\begin{array}{l}\text { Blood loss } \\
\text { mean (SD) }\end{array}$ & $\mathbf{t}$ & df & Sig & $\begin{array}{l}\text { Mean } \\
\text { difference }\end{array}$ & $\begin{array}{l}\text { Std. error } \\
\text { difference }\end{array}$ & 95\% CI \\
\hline Before placental delivery & $296.8(102.45)$ & -6.666 & 98 & 0.000 & -155.2 & 23.283 & -201.4 to -108.99 \\
\hline After placental delivery & $452.0(128.87)$ & -625 & & & &
\end{tabular}

*Test of significance $=$ unpaired $t$ test, Equality of variances had been assumed by Levene's test for equality of variances.

There was no statistically significant difference between the study and control group in respect to age, education, socio-economic status, religion, gravida and parity $(>0.05)$. Therefore, both the groups were comparable to each other (Table 2).

There was no statistically significant difference in incidence of PPH with difference in timing of administration of oxytocin ( $p>0.05)$ (Table 3). But there was statistically significant decrease in mean blood loss if oxytocin was administered before the placental delivery (Table 4).

\section{DISCUSSION}

This study revealed that there was no difference in incidence of $\mathrm{PPH}$ with difference in timing of administration of oxytocin. Nadim AA et al, Jackson KW et al, Soltani $\mathrm{H}$ et al, in their previous researches similarly found that timing of administration of oxytocin had no impact in the change of occurrence of the event of PPH, while Huh WK et al, reported that incidence of PPH was found to be significantly lower in the group when oxytocin was administered after placental delivery. $1,16,17,20$

However, in this study when mean blood loss amount had been compared between the two groups, it was clearly evident that mean blood loss was significantly less if oxytocin administered before placental delivery than after placental delivery. Similar findings had been demonstrated in previous researches by Mohamadian S et al, Orhan EO et al. ${ }^{18,19}$

Timing of administration of oxytocin remained a matter of debate since it had become an important drug to prevent occurrence of an event of PPH. In every country, especially in developing country where load of deliveries could not be managed adequately due to shortage of manpower in frequent intervals, policies regarding timing of administration and adequate training of labour room staffs regarding that is an utmost need. Researches in different settings are conducted all throughout the world to address this issue. The current study is one such attempt. The strategy of policy making is to keep in mind not only the fact that incidence of PPH has not been affected by timing of administration of oxytocin, also mean blood loss amount is to be considered.

This study faced the limitations like small sample size, resource constraints leading to non-consideration of other outcome variables like duration of third stage labour, incidence of retained placenta etc.

\section{CONCLUSION}

The current study found that the incidence of postpartum haemorrhage did not differ significantly between the two groups $(4 \%$ versus $14 \%$; Chi-square $=3.053, \mathrm{df}=1$, $\mathrm{p}=0.081$ ). But oxytocin given before placental delivery resulted in lower blood loss (296.8 versus $452 \mathrm{ml}$; p $<0.05)$.

Therefore, though flexibility in timing of administration can be included in standard operational guideline in labour room, but it should be kept in mind that it is preferable to administer it before delivery of placenta as this application decreases mean blood loss during third stage of labour which is an important issue in a context where majority of mothers delivering are suffering from anaemia.

Funding: No funding sources

Conflict of interest: None declared

Ethical approval: The study was approved by the Institutional Ethics Committee

\section{REFERENCES}

1. Nadim AA, Yehia AH, Farghal RM. Prophylactic oxytocin before versus after placental delivery to reduce blood loss in vaginal delivery: a randomized controlled trial. J Women's Health Reprod Med. 2017;1(6):1-4.

2. WHO guidelines for the management of postpartum haemorrhage and retained placenta, 2009. Available at:

https://apps.who.int/iris/bitstream/handle/10665/441 71/9789241598514_eng.pdf;jsessionid=6932AE03E CB834C63659DCAEA0033216? sequence $=1$. Accessed on $12^{\text {th }}$ January 2019.

3. WHO recommendations for the prevention and treatment of postpartum haemorrhage, 2012. Available at: https://apps.who.int/iris/bitstream/handle/10665/754 11/9789241548502_eng.pdf?sequence $=1$. Accessed on $12^{\text {th }}$ January 2019.

4. Anderson JM, Etches D. Prevention and management of postpartum haemorrhage. Am Family Phy. 2007;75(6):875-82. 
5. Barbieri RL. Routine use of oxytocin at birth: just the right amount to prevent postpartum hemorrhage. OBG Manag. 2012;24(7):8-11.

6. Willis CE, Livingstone V. Infant insufficient milk syndrome associated with maternal postpartum hemorrhage. J Hum Lact. 1995;11:123-6.

7. Sert M, Tetiker T, Kirim S, Kocak M. Clinical report of 28 patients with Sheehan's syndrome. Endocr J. 2003;50:297-301.

8. Reyal F, Deffarges J, Luton D, Blot P, Oury JF, Sibony O. Severe post-partum hemorrhage: descriptive study at the Robert-Debre Hospital maternity ward French. J Gynecol Obstet Biol Reprod (Paris). 2002;31:358-64.

9. Corwin EJ, Murray-Kolb LE, Beard JL. Low hemoglobin level is a risk factor for postpartum depression. J Nutr. 2003;133:4139-42.

10. Ekeroma AJ, Ansari A, Stirrat GM. Blood transfusion in obstetrics and gynaecology. $\mathrm{Br} \mathrm{J}$ Obstet Gynaecol. 1997;104:278-84.

11. World Health Organization. Managing complication in pregnancy and childbirth: a guide for midwives and doctors. Geneva: WHO; 2000. Available at: http://www.who.int/reproductivehealth/publications/ maternal_perinatal_ health/9241545879/en/index.html. Accessed on $12^{\text {th }}$ January 2019.

12. Bais JM, Eskes M, Pel M, Bonsel GJ, Bleker OP. Postpartum haemorrhage in nulliparous women: incidence and risk factors in low and high-risk women. A Dutch population-based cohort study on standard $(>$ or $=500 \mathrm{~mL})$ and severe $(>$ or $=1000$ $\mathrm{mL}$ ) postpartum haemorrhage. Eur J Obstet Gynecol Reprod Biol. 2004;115:166-72.

13. Magann EF, Evans S, Chauhan SP, Lanneau G, Fisk $\mathrm{AD}$, Morrison JC. The length of the third stage of labor and the risk of postpartum hemorrhage. Obstet Gynecol. 2005;105:290-3.

14. Combs CA, Murphy EL, Laros RK. Factors associated with postpartum hemorrhage with vaginal birth. Obstet Gynecol. 1991;77:69-76.
15. Stones RW, Paterson CM, Saunders NJ. Risk factors for major obstetric haemorrhage. Eur J Obstet Gynecol Reprod Biol. 1993;48:15-8.

16. Jackson KW, Allbert JR, Schemmer GK, Elliot M, Humphrey A, Taylor J. A randomized controlled trial comparing oxytocin administration before and after placental delivery in the prevention of postpartum hemorrhage. Am J Obstet Gynecol. 2001;185(4):873-7.

17. Huh WK, Chelmow D, Malone FD. A doubleblinded, randomized, controlled trial of oxytocin at the beginning versus the end of the third stage of labour for prevention of postpartum hemorrhage. Gynecol Obstet Invest. 2004;58:72-6.

18. Mohamadian S, Jahani SN, Mirzakhani K. The effect of the timing of oxytocin intramuscular injection on maternal bleeding during the third stage of labour. J Midwifery Womens Health. 2014;1:66-70.

19. Orhan EO, Dilbaz B, Aksakal SE, Altınbas S, Erkaya S. Prospective randomized trial of oxytocin administration for active management of the third stage of labor. Int J Gynaecol Obstet. 2014;127:1759.

20. Soltani H, Hutchon DR, Poulose TA. Timing of prophylactic uterotonics for the third stage of labour after vaginal birth. Cochrane Database Syst Rev. 2010;8:CD006173.

Cite this article as: Kirtania R, Pal J, Biswas S, Aich A. A randomized controlled trial comparing oxytocin administration before and after placental delivery in the prevention of postpartum haemorrhage in a tertiary care hospital in Bankura district of West Bengal, India. Int J Reprod Contracept Obstet Gynecol 2020;9:1976-80. 